\title{
北海道大学中川研究林における道路建設予定地の生態系評価に向けて
}

\author{
池上佳志 \\ 北海道大学北方生物圈フィールド科学センター 098-2501 中川郡音威子府村 北海道大学中川研究林
}

\section{Introduction of study site for ecosystem evaluation and monitoring under planning road construction in Nakagawa research forest, Hokkaido University}

Yoshiyuki IKEGAMI

Nakagawa Research Forest, Hokkaido University, Otoineppu Hokkaido, 098-2501 Japan

はじめに

北海道大学中川研究林を主たる対象として「一 般国道音威子府バイパス (中川一音威子府)」事業 (以下, 音威子府バイパス事業)が進められている。 現在, 環境影響評価手続きが進められ, 準備書が終 了した段階である.バイパス道路が建設されれば, 周辺の自然環境における変化は免れることはなく, 現在および将来的に生態系の把握と管理を検討す る必要がある。人間による改変行為が大規模であ る場合，その影響が広域にわたることが考えられ るので, このような検討は, 局所地域だけでなく, 広域において行われる必要がある。広域的な生態 系の把握, 評価から管理指針を提示すること,また 人間活動による自然への影響を捉えていくことは, 景観生態学だけでなく，自然科学における今日的 課題と言えよう。

筆者は，以前より環境計画に興味を持ち，地域 の自然環境の総合的把握から植生や土地利用の立 地条件を明らかにすることを目的とした研究を進 めて来た（池上, $1996 ; 2000)$. 現在, この音威子 府バイパス事業を背景として, 景観生態学的な視 点から「広域的な森林域生態系の把握とその機能 評価に関する研究」に取り組み始めた. 本稿では研 究サイトおよび当研究計画を示し, 多方面の研究 者の方からご意見やご協力を賜ると同時に情報交 換の機会としたい.

\section{北海道大学中川研究林}

北海道大学中川研究林は, 1902 年の札幌農学校 時代に第二基本林として設定された，道北地域を 北流する天塩川中流域の中川町と音威子府村に位 置している。ペンケ山 $(716 \mathrm{~m})$ とパンケ山 $(631 \mathrm{~m})$ を主峰とし，面積約 19,000 ha を有する．当地は亜 寒帯に属し, トドマツ, エゾマツ, ミズナラ, イタ ヤカエデなどで構成される沉針広混交林が広がる。
キタコブシ，カッラなど温帯性樹種の北限とされ ている.地質は堆積岩を主とするが, 塩基性の強い 蛇紋岩が帯状に分布し，地質的にも植生的にも独 特の環境が存在する，全域が鳥獣保護区に指定さ れ，「すぐれた自然地域 (北海道環境科学研究セン ター, 1994)」としても認められている。

中川研究林では,「北方森林の長期動態のメカニ ズムの解明」を大課題として様々な調査・研究が進 められている。筬島原生保存地区とパンケ原生保 存地区が原生林保存林として設定され，それぞれ 針広混交林とアカエゾマツ林(蛇紋岩地を含む)が 開拓以来手つかずの状態で保存されるとともに， その長期的遷移の観察が行われている。照査法試 験林では成長量に見合った伐採を行い，持続的資 源利用を 30 年にわたって検討している（和ほか 1998）。孤立林試験地では伐開によって孤立化させ た林分を創出し，その森林の動態と回復過程を調 査している (奥田・日浦, 1997)。この試験地は, 日 本における数少ないフラグメンテーション，アイ ソレーションに関する研究サイトであり，共同研 究などの推進が期待されている。これらを含めて 60 力所以上の長期観察林と 300 を越える更新地に ついて，樹木の成長など森林の動態を調査してい る。それらのデー夕を利用し, 主要構成木の成長特 性など北方林における森林動態の一部が明らかに なってきている（日浦ほか，1998）.

\section{音威子府バイパス事業に関わる取り組み}

「一般国道音威子府バイパス (中川－音威子府)」 事業 (国土交通省北海道局) は, 国や北海道におけ る上位の総合開発計画の一環として位置づけられ， 音威子府村 $(1,250$ 人) と中川町 $(2,500$ 人) を結ぶ 区間を対象として進められている。事業対象地と して, 中川研究林を通過するルート, 国有林を通過 するルートなど, 複数の路線が検討されてきた.中 
川研究林 (当時, 農学部附属演習林中川地方演習 林）は原生自然の保護などを訴えてきたが, 地元か らの強い要望もあり, 地域振興の観点から両町村 市街地に接する中川研究林通過ルート（延長約 $19 \mathrm{~km}$ ）が計画路線として採用された。当地は, 崩 壊しやすい蛇紋岩を含む急峻な地形、豪雪地帯で あり, 計画路線の近傍には原生保存林、複数の猛禽 類営巣地, サケ・マス遡上河川など貴重な自然環境 が残存する。このようなことから、大部分でトンネ ル構造が採用される.ただし, 地上走行部分は, 河 川谷底を縦断する部分と草地と森林の境界線に 沿った部分となる。このような自然環境を対象と して, 環境影響評価が進められ,すでに環境影響評 価準備書が終了している. 現在, 中大型ほ乳類や猛 禽類を対象とした追加調査が継続されているが, 後に評価書が作成され, 環境影響評価手続きが終 了することになる。

事業アセスメントに関する調査が進められる一 方で, 中川研究林では国土交通省北海道局の支援 を受けて「中川地方演習林 (中川研究林) における 自然環境調査」を行っている (北海道大学農学部附 属演習林中川地方演習林, 1998 ；1999；2000).こ の調査は, 道路建設が自然環境に与える影響を長 期的にモニタリングする目的であり, 工事前, 工事 中, 工事完成後の 3 段階に分けて調査を行い, 最終 的には 3 段階それぞれのデー夕を対比して総合的 な結論を得る計画とされている.工事前には, 現況 の自然環境 (植物, 動物, 昆虫, 魚類, 菌類など) を出来る限り把握し, 初期値としての情報を収集 する.工事中は, 裸地形成や工作物の作設にともな う自然環境への影響を調査, 完成後には, 法面や工 作物，通行車両による自然環境への影響を調査す ることになっている（金子ほか, 1999). 現在, 学 内外の研究者の協力を得て, 内陸性オジロワシや クマタカの営巣状況のモニタリングをはじめとし て，20を越える様々な調査が進められている（表 $1)$.

地域的な取り組みとして「自然と共存する地域 づくりに関する調查・研究推進委員会 (通称, 地域 づくり委員会)」が発足している. 北海道局関係者, 中川研究林関係者, 地元自治体住民を構成員とし て, 自然環境保全や地域振興に関する様々な検討 がされている.例えば, 当バイパスをエコロードと して位置づけ, 貴重種に対するミティゲーション 措置, 動物の移動経路の確保, 表土復元などによる
自生種による緑化, 地元からの苗木供給システム の構築などが課題として挙げられている.

\section{道路建設予定地における生態系評価に向けて}

筆者は,このような開発計画を背景として「広 域的な森林域生態系の把握とその機能評価に関す る研究」を進めようとしている。この研究では音威 子府バイパス事業の進行を追い, 関係資料を参考 にしながら, 自然環境の分析の目的, 手順, 方法に ついて検証し, 広域的な森林域生態系における概 略的, あるいは複数の機能の把握, 評価の手法とそ の適用結果を提示する予定である.ささらに, その成 果をもとに当地における生態系管理について検討 したいと考えている.

\section{1）広域における自然環境の把握と特性の抽出}

まず初めに, 周辺地域を含めて自然環境の状態 を把握し, 当該地の自然環境の特性を明らかにす ることによって，広域的な位置づけを明らかにす る必要がある。一般的に,このような検討は開発計 画の構想段階に捉えられているべき課題である. 一般的な報告書などでは, 当地のみの資料が示さ れ他地域との比較として捉えることができなかっ たり，文章として抽象的に記述されてはいるもの の具体的な分布図が示されなかったりする場合が 多く見受けられる.このような分析を行う場合は， 広域的な自然環境の比較から当地あるいはその周 辺地域の特殊性や典型性を検討して, それを地図 上で区分しその配置や分布を明確にする必要があ ろう. 当研究では, 現在のバイパス建設予定地であ る中川研究林南部だけでなく, その周辺の道有林, 国有林を含めて約 $15,000 \mathrm{ha}$ を対象として, 当該地 の自然環境の特性を把握する予定である.

\section{2）概略的把握と機能別の把握}

広域を対象にして,当該地域の自然環境の特性, すなわち特殊性や典型性を捉える場合の方法とし て，2つの手法が考えられる．1つは，入手可能な 地理情報を網羅し, 環境の特殊性や希少性, 立地の 特異性, 地域内での当該環境の希少性などから, 自 然環境の特性を示すような概略的な把握である。 もう1つは, 木材生産機能や水源涵養機能, 山地災 害防止機能, 環境保全機能などの森林の機能別に, 環境特性を把握するものである。ここでいう特殊 性とは周辺地域との比較, あるいは当該地内で特 異に見いだされる性質であり, 典型性とは周辺地 域で，あるいは当該地内で全般に見られる性質の 
ことを指す。

概略的把握は, 得られた地理情報のみから妥当 な判断をしょうとするものであり，特定の機能を 精度良く評価することはできないが，基盤として の自然環境の違いを抽出することによって，ポテ ンシャルとしての特性を示すことができると考え られる，既存の情報や最低限の現地調査から迅速 に成果を得ることができる。一方, 特定の機能に注 目して環境特性を明らかにした方が，より精度が 高く,わかりやすい結果を得ることができよう.た だし，そのためには，その機能を発揮するためのメ カニズムが明らかになっている必要があり, 広域
的な解析においてはそのメカニズムに関わる環境 要因のデー夕が整備されている必要がある. 後者 の方法が望ましいが, メカニズムの理解が必要で あり，それを広域的に適用したような事例は未だ 少ない。

\section{3）森林域生態系の機能の把握}

本研究では, 概略的把握を早急に行うとともに, その結果を参考にしながら機能別評価の種々の課 題に取り組んでいく予定である。概略的把握に よって示された立地環境の相違は, サンプリング サイトの選定や既存情報の理解に利用される．例 えば，水源涵養機能を評価するためのサンプリン

表 1.中川地方演習林における自然環境調査（1997-1999 年研究課題一覧）

\section{7 年度報告}

オジロワシ生態調查-中間報告-

1997年度中川演習林コウモリ類調査報告

風衝地における樹木の生長

蛇紋岩地帯における地すべり堆積物の分布域推定と動態観測

アユマナイ川における土砂移動の形態と長期観察

中川地方演習林における淡水魚類相の特徵

\section{8 年度報告}

オジロワシ生態調査 -98 年度報告-

中川地方演習林内におけるネズミ個体群の遺伝的空間構造

ヒグマの生態調査

地表性甲虫群集を利用した断片化した自然林の評価

道北の針広混交林におけるササの影響

北海道北部のヨーロッパトウヒ林に発生する

リター分解菌の種組成および空間分布

中川演習林のガ類相

サッコタン川における土砂移動の状況

ーアユマナイ川 (琴平川) の土砂移動形態との比較から-

R4 0 号の自然環境への影響調査I

一森林を分断した場合の森林植物相の変化について一

\section{9 年度報告}

希少猛禽類生態調査

秋季におけるヒグマ食性と利用地の年次変化に関する研究

中川地方演習林内におけるネズミ個体群の遺伝的空間構造 1999年度中川演習林内コウモリ類調査

地表性甲虫群集を利用した断片化した自然林の評価（1999中間報告）

中川演習林のガ類相（中間報告）

道路凍結防止剂の動植物への影響

道路凍結防止剤の植物への影響 [日林北支論]

樹木の傷害応答 : 2 次代謝物の異常応答

道北の針広混交林における天然更新に及ぼすササの影響

森林を分断化した場合の森林植物相の変化-1999年度報告- 
グサイト（この場合は小集水域など）を選定した り, あるいは環境保全機能の 1 つとして, 確認情報 やセンサスによる調查から動植物の生息・生育地 の環境特性を抽出したりするために利用できると 考えられる。その他にも長期観察林や更新地成績 調査などのデー夕を立地と対応させて分析し，樹 木の成長特性や森林の動態などから木材生産機能 を検討したり, 蛇紋岩带や崩壊地, 地形, 周辺植生 の分布から山地災害防止機能を検討したりするこ とが可能だと考えている.

広域的な評価を行うためには，様々な地理情報 が基盤情報として必要となる. 当地では, 地菰, 地 質, 植生, 土地利用, 森林蓄積量, 河川, 土地所有, 法規制，可能であれば貴重な動植物の分布などの 地理情報をデータベース化し, 解析に利用する予 定である.ただし, 機能別の把握を行うためには, これらの入手可能な地理情報だけでなく, 新たな データやより詳細なスケールでの地理情報が必要 になると考えられる．機能別把握のために必要と なる新たな地理情報を発見することは，当研究の 課題の一つである．逆に森林域生態系の機能を説 明するメカニズムと直接に関わっていなくとも， 機能を発揮している場所と相関の高いマクロな地 理情報を発見することも課題である。

\section{4）生態系評価と生態系管理}

以上のような検討から，それぞれの機能を評価 するための手法とその結果得られた知見を提示す るとともに，その成果をもとに当地における自然 環境の評価とその管理について検討することが最 終的なゴールである.

上述のような,自然環境の特性の概略的把握, 機 能別の把握といった研究は, 個別の自然現象を詳 細に明らかにしていく基礎的研究とは異なり, マ クロな視点から広域の環境を捉えようとするもの である。これは実践的な要求から進められる応用 的研究であり, 既定の学問概念から見ると研究と して疑問視される場合もあろう。しかし，実際にそ のような要求があり, 国際的にも種々の事例が示 されてきている。

実践的，応用的な研究では，その問題の総合的 な結論を得ることは難しく，一事例における手法 や知見，検討結果の提示が行われる場合が多いで あろう. 実践・応用研究が扱う課題は, 複雑なこと が多く, 短期間に結論が得られることは少ないと 考えられる. 実践的, 応用的な研究で提示された成
果は, 総合的な結論を得るための “たたき台”ある いは“選択肢としての一視点からの評価”だと捉え ることが出来よう。そのような成果に, 完全性を求 めるのはほぼ不可能であり, より完成度をあげる ためには，基礎的なテーマを扱っている研究者を 含めて議論を重ね, その成果を改善していく必要 があろう. 実際の意志決定の場では, 様々な視点か らの選択肢が必要であり, 実践的, 応用的研究によ る“たたき台”あるいは“選択肢としての一視点か らの評価”の提示は十分に意義のあることだと考 えられる. 複数の選択肢が提示された上で, 行政, 研究者, 住民などのさまざまな視点から,さまざま な意見の中で, 最終的な意志決定が行われるべき である。

\section{プロジェクト研究の必要性}

「景観生態学は, 生態学的なシステムや群集, 八 ビタット，そして個々の生物の組み合わせから認 識することのできる “空間”を扱う研究分野」であ り,その視点や成果が持続的なランドスケープ・マ ネジメントのために重要である (Golley, 1996). 基 礎的研究が進められる一方で, 実際のランドス ケープ・マネジメントを背景とした実践的な取り 組みから，研究課題を選択して実行することも必 要ではなかろうか. 広域を対象としたり,複数の視 点を含んだ大規模なプロジェクト，あるいは大規 模な野外実験を成功させるためには, 興味をとも にし, 多くの議論をすることができる複数の研究 者の協力が必要である.海外では, 景観生態学だけ でなく, 様々な分野で共同研究や大規模プロジェ クトが進められているようである.

当地におけるバイパス建設事業に関する話題は, ランドスケープ・マネジメントを考える上で好適 な課題の 1 つであると考えている.「中川研究林に おける自然環境調査」が進められているが, 幅広い 項目を対象とした長期モニタリングを目的として いるため，現時点では個別の興味で進められてい るのみである。それらを含めた総合的な検討を行 う余地がある.地域づくり委員会で挙げられてい る検討課題は，実際に求められている課題と言え よう。当地の社会環境に関する調査の不足も指摘 できる。このような課題をすべて実行するのは困 難であるが，いくらかのまとまりによって大規模 プロジェクトとして推進する価值があると考えて いる. 
当バイパス事業に関する話題は, 上述の研究計 画だけであっても単独で進めるには課題が大きす ぎる.本稿に示した課題を実行するだけでも, 多大 な時間と費用, 能力が必要となる。本研究を進める にあたり，「中川研究林における自然環境調査」に 関わる委任経理金の一部,「日本学術振興会 科学研 究費 (奨励研究(A)13780443)」を利用している。ま た, データ作成等においては, 北海道環境科学研究 センターの協力を得ている. しかし, 当研究計画を 完結するには，さらなる協力体制を得たいと考え ている.

$$
\text { メッセージ }
$$

私は, 中川研究林および道路建設予定地周辺の 生態系管理に関する研究を, 共同研究, プロジェク 卜研究を進めるにあたって好適な研究サイトと考 えて, 本誌に紹介させていただきました。本稿の揭 載を許していただいた編集事務局と，本稿を読ん でいただけた読者の皆様に深謝いたします。多く のご意見, 問い合わせ, 共同研究の提案などをいた だければ幸いです。

\section{引用文献}

Golley, F.B. 1996. A state of transition. Landscape Ecology, 11: 321-324.

日浦勉 ·上島信彦 · 奥田篤志 - 北條 元 ·石田亘生 $\cdot$ 奥山悟. 1998. 北海道中川演習林の北方針広混 交林におけるトドマツ、ミズナラ、イタヤカエ デの直径成長におよぼす込み合い効果. 北大演 研報 55(2)：255-261.

池上佳志. 1996. 環境計画のための景観生態学的 研究-瀬戸内における事例と計画策定の検討. 国 際景観生態学会日本支部会報, 3(1)：2-9.

池上佳志. 2000. 景観構造の分析とその環境保全 計画への適用に関する研究 [学位 (博士) 論文 要 旨]. 広島大学総合科学部紀要IV理系編, 26:131-
135.

金子潔·野田真人·車柱榮·山ノ内誠·守田英明· 奥田篤志・水野久男. 1999. 中川演習林に扔け る自然環境調查. 北方森林保全技術, 17:43-48. 和 孝雄 - 小鹿勝利 - 神沼公三郎 - 夏目俊二 - 米康 充·守田英明 - 藤戸永志 · 北條 元. 1998. 照査 法試験林の施業経過と成績(「)一北海道大学中 川地方演習林の試験林の分析一。北大演研報, $55: 274-308$.

北海道大学農学部附属演習林 中川地方演習林.

1998. 中川地方演習林における自然環境調査一 1997年度報告一. 北海道大学農学部附属演習林 中川地方演習林.

北海道大学農学部附属演習林 中川地方演習林. 1999. 中川地方演習林における自然環境調査一 1998年度報告一. 北海道大学農学部附属演習林 中川地方演習林.

北海道大学農学部附属演習林 中川地方演習林. 2000. 中川地方演習林における自然環境調査一 1999年度報告一. 北海道大学農学部附属演習林 中川地方演習林.

北海道環境科学研究センター. 1994.「すぐれた自 然地域」自然環境調査報告書 道北圈域 - 道央圈 域. 北海道環境科学研究センター。

奥田篤志 - 日浦 勉. 1997. 中川地方演習林におけ る孤立林の調査計画. 北大演試験年報, 15:8-10.

\section{関連情報}

「一般国道音威子府バイパス (中川一音威子府)」事 業に関する情報 北海道開発局 http://www.hda.go.jp/hdb/zigyoka/z_kankyo/otoi/ 北海道開発局旭川開発建設部

http://internet5.hkd.mlit.go.jp/as/road1/jigyo/ jigyo04.html 